\title{
71- More than a pilgrim less than a wife: Harry Bailly in Geoffrey Chaucer's The Canterbury Tales ${ }^{1}$
}

Nazan YILDIZ2

APA: Yıldız, N. (2021). More than a pilgrim less than a wife: Harry Bailly in Geoffrey Chaucer's The Canterbury Tales. RumeliDE Dil ve Edebiyat Araştırmaları Dergisi, (25), 1140-1150. DOI: 10.29000/rumelide.1037408.

\begin{abstract}
Geoffrey Chaucer's pilgrims in his monumental work The Canterbury Tales have been widely treated by the scholars who produced copious articles and books on the countless matters focusing on each pilgrim. Nevertheless, little attention has been paid to Harry Bailly, the striking innkeeper of the text. Bailly guides a group of medieval people of different ranks to the shrine of Saint Thomas Becket in Canterbury which introduces the reader to the greatest panorama of the medieval period. As the main framework of the text, Bailly asks pilgrims to tell stories on their way to Canterbury. Bailly does not tell a story himself; yet, he becomes so successful in handling of the disputes among the pilgrims and putting all of them in order; and every time he has a say for the stories as well as the story tellers. He is also very cautious about the traditional three estates order which constitutes the backbone of the medieval society. The Canterbury Tales can be envisaged without any of its pilgrims, but not without a Harry Bailly. He is the authoritative figure, and a know-it-all. Throughout the text, he performs divergent roles as a host, a leader, a judge, a critic and a governor. Although his commanding position is impeded by his domineering wife, taken as another Wife of Bath in the paper, Bailly occupies a unique position as the maestro of the pilgrims. Accordingly, this paper aims to dwell on Harry Bailly in the Canterbury Tales to present him as the inalienable yet neglected character of the masterpiece of Geoffrey Chaucer.
\end{abstract}

Keywords: Geoffrey Chaucer, the Canterbury Tales, medieval period, Harry Bailly

\section{Bir hacıdan daha fazla, bir eşten daha az: Geoffrey Chaucer'ın Canterbury Hikâyelerindeki Harry Bailly karakteri}

$\ddot{O} \mathbf{z}$

Geoffrey Chaucer'ın dev yapıtı Canterbury Hikâyelerindeki hacı karakterleri her hacı üzerine farklı konularda sayısız makale ve kitap üreten araştırmacılar tarafından geniş ölçüde ele alınmıştır. Fakat metnin göz alıcı hancı karakteri Harry Bailly’e çok az ilgi gösterilmiştir. Bailly farklı sınıflara mensup bir grup Orta Çağ insanına Canterbury'deki aziz Thomas Becket’in türbesine giderken rehberlik eder ve okuyucuya Orta Çă̆'ın en kapsamlı resmini sunar. Bailly metnin ana çerçevesi olarak hacılardan Canterbury yolunda hikâye anlatmalarını ister. Kendisi bir hikâye anlatmaz fakat hacılar arasındaki tartışmaları yönetmede ve onları bir düzene sokmada çok başarılıdır; her zaman hem hikâyeler hem de onları anlatanlar için söyleyecek bir sözü vardır. Orta Çağ toplumunun belkemiğini oluşturan üç sınıf düzeni ile ilgili de çok ihtiyatlıdır. Canterbury Hikâyeleri herhangi bir hacı karakteri olmadan

This article is the revised version of the paper delivered in October 2021 entitled "More than a pilgrim: Harry Bailly in Geoffrey Chaucer's The Canterbury Tales" at the 14th International Idea Conference: Studies in English organised by Karadeniz Technical University in Trabzon, Turkey.

Dr. Öğr. Üyesi, Karadeniz Teknik Üniversitesi, Edebiyat Fakültesi, İngiliz Dili ve Edebiyatı Bölümü (Trabzon, Türkiye), nazanyildiz1@hotmail.com, ORCID ID: 0ooo-0002-5776-0268 [Araştırma makalesi, Makale kayıt tarihi: 15.11.2021kabul tarihi: 20.12.2021; DOI: 10.29000/rumelide.1037408] 
düşünülebilir fakat bir Harry Bailly olmadan Canterbury Hikâyeleri düşünülemez. Otoriter ve her şey hakkında bir bilgisi olan Bailly, metin boyunca hancı, lider, hakem, eleştirmen ve yönetici gibi farklı roller üstlenir. Hükmeden konumu makalede başka bir Bath'lı Kadın olarak ele alınan baskıcı karısı tarafından sekteye uğrasa da, Bailly hacıların orkestra şefi olarak eşsiz bir yere sahiptir. Bu bağlamda, bu makalenin amacı Canterbury Hikâyelerindeki Harry Bailly'e odaklanıp, onu Geoffrey Chaucer'ın başyapıtındaki yeri doldurulamaz fakat ihmal edilmiş bir karakter olarak ele almaktır.

Anahtar kelimeler: Geoffrey Chaucer, Canterbury Hikayeleri, Orta Çağ, Harry Bailly

\section{Introduction: Critics on Harry Bailly, His Sundry Roles and Functions}

Despite of his matchless seat in The Canterbury Tales, compared to other pilgrims, Harry Bailly has been mostly ignored by Chaucer critics as he is generally mentioned but not treated at length. 3 Being an innkepeeper, Bailly is at the center of the medieval community and, like Chaucer himself, he has the chance to interact with medieval people coming from the different walks of life. Thus, after the Franklin, Bailly can be regarded as the closest character to Chaucer himself. One can not be sure whether Chaucer inspired from a real person while creating his outstanding innkepeeper; yet, to Manly and Malone, Chaucer might be motivated by a real innkeeper (1926, p.79), who is an innkeeper of the Tabard Inn in Southwark, called "Henri Bayliff" (1950, p.209). No matter purely fictional or partly real, Harry Bailly is the mainstay of the Canterbury Tales. Malone defines Bailly as "a bully or a clown or an upstart, someone who barely holds the pilgrimage together and who provides comic relief" (1950, p.209). To Richardson, Bailly is generally very cordial to the pilgrims, who, in reply to, esteem him (1970, p.325). For Page, the Host "is a time-bound and earth-bound man, and in the scheme of the Canterbury Tales he represents the immediate present. He is both in and of this World" (1969, p.11). Scheps foregrounds the masculine character of the host and points out that he "is big, strong, handsome (perhaps even heroic), wise, generous, decisive, irascible, impudent (to the Franklin), pugnacious (to the Pardoner)" (1975, p.114). According to Pugh, Bailly serves as a "governing figure, as ruler, as king" of the journey to Canterbury, and he also symbolizes a "figure of bourgeois masculinity," along with a "recognizable type of the proud man" (2006, p. 39). Similar to Scheps and Pugh, Keen underlines the heroic traits of the Host especially by taking his very first description into account (1969, p.10). Basing on his self-esteem, Pichaske and Sweetland delineate Bailly as "more than a literary arbiter" and specify him as "the elected medieval monarch governing this pilgrim society" (1977, p.184). Examining the Host, Sedwick and Mann call attention to his middle-class characteristics. For Sedwick, Bailly is "a picture of the truest typical Englishman that has ever been deliniated" (1934, p.237); and for Mann, he stands for the "middle-class standards" due to his attitudes towards the pilgrims as he behaves them in line with their estates (1973,p.1-7). There are two characters conducting the pilgrimage: "Geoffrey the Narrator and Harry the Commentator", Richardson claims (1970, p.326). Therefore, Bailly, with his masculine attributes and assertive demeanors, is underscored by critics as the guide and ruler of the pilgrims whose stories he evaluates like a critic. With his story telling competition, the reader is introduced into the medieval world and personalities. Drawing lessons from the tales, Bailly also meets the main function of the medieval texts. Yet, if taken as the spokesman of Chaucer, rather than preaching, he is for fun and entertainment. In fact, Bailly seems as the central medium of Chaucer's ambigious and humorous tone throughout the Canterbury Tales, which is in accordance with the well-known phrase used for Chaucer's

The Host of Chaucer's The Canterbury Tales has drawn relatively little critical attention. As he does not have a story, he is largely treated second degree in the framework of his interactions with other pilgrims in the transitions between the tales. Few studies are dedicated entirely to him. In Turkey, there is not even a thesis written on Harry Bailly. 
style in the text, especially compared to William Langland: laughing with his characters rather than laughing at them.

Keeping his hilarious yet dominating guidance in the entire journey, Bailly, apart from his various roles, possesses diverse functions in the Canterbury Tales. To Richardson, the function of Bailly is strictly related to his sagacity, his pomposity, his obsession with time and sex, his position as a middle-class host, his playfulness, and his pettishness (1970, p.326). Richardson further lists the main functions of the host. Initially, Richardson features the story telling contest suggested by Bailly as it constitutes the organic medium for the sheme of the tales. The contest is also essential because through the contest Chaucer implies that everything in life is related and linked to each other. Furthermore, by the contest, the reader is informed not only about the characters but the interactions among them. Secondly, as an innkeeper, Bailly keeps a symbolic position since the medieval inn was the only location where such a varied group of people could gather. What is more, the medieval inn was also a venue for shelter, guidance and merriment. 4 Lastly, Bailly comes from the middle class representing "an Everyman"; more importantly, he largely epitomizes the troubles and requisites of "a very small but growing class, one that was increasingly monied, mobile, and literate but also ill-educated, unsophisticated, and impatient with artistic subtleties" (1970, p.327). For Fredrica, Chaucer employs Bailly as a dramatic means to fill the void between "the worlds of reality and fiction" (1978, p.1). As claimed by Fredrica, his presence is vital to the plausibility of the whole poem since he is a realistic character due to his interactions with the pilgrims (1978, p.1).

In terms of structure, Chaucer critics regard Bailly as a connecting device and as audience for Chaucer. To Limuansky, editors also serve as link providers helping to organize and build up a "well-defined and well-lit group of pilgrims with connecting tales and creating a unified framework" (1955, p.85). Analogous to his editors, Bailly, Legouis suggests, "is always present on stage, and is the real center of the comedy which is being enacted on the road. He gives unity to the whole poem, where he plays the part of the ever-present protoganist" (1961, p.175). Muscatine is another critic writing on the structural unity of the poem by affirming that the Host "closes the gap between both worlds, the world of the travelers and tales" (1957, p.171). Muscatine, furthermore, underlines the function of Bailly as a "Greek chorus" in the poem, remarking that he acts "as a mediator between the worlds of the tales and the tellers, director of both, with his choric activity linking both" (1957, p.171). Thus, Bailly is the character who gives the poem the unity and believability by the story telling contest and he is the one who controls the flow of the poem by directing the pilgrims. Moreover, as a middle-class member, he stands for the characteristics and values of the newly emerging class of the medieval period apart form the clergy, the nobility and the commoners. 5 Bearing in mind that Chaucer himself belongs to this middle class, Bailly's role gains more significant in Chaucer's criticism in which a hot debate on whether Chaucer is for or against the middle class or grouping of his period pervades. ${ }^{6}$ The examination of Bailly's role and

$4 \quad$ For detailed information on the medieval inns, see Thomas C. Richardson "Harry Bailly: Chaucer's Innkeeper" in Chaucer's Pilgrims: An Historical Guide to the Pilgrims in The Canterbury Tales. Eds. Laura C. and Robert T. Lambdin. Westport: Praeger, (1996): 324-339. John Hare's "Inns, Innkeepers and the Society of Later Medieval England, 1350160o" in Journal of Medieval History, (2013), 39. 4: 447-497.

$5 \quad$ The medieval people who did not fit into any of the three estates; namely, the clergy, the nobility and the commoners, are largely defined as the representatives of "the middle-grouping" "strata" or "class". In relation to the application of the phrase, read Morris Bishop, The Penguin Book of the Middle Ages (Norwich: Fletcher and Son, 1971) 308; Paul Strohm, Social Chaucer (Cambridge and Massachusetts: Harvard UP, 1989) 4-5; and Marion Turner, "Politics and London Life."A Concise Companion to Chaucer. Ed. Corinne Saunders (Oxford: Blackwell, 2006) 29-30.

$6 \quad$ There are disputes over Chaucer's handling of the three estates and the "middle-grouping" in his Canterbury Tales. According to the initial opinion, Chaucer saves a common belief of the medieval society and is faithful to the three estates structure (For example, Gerald Morgan, "Moral and Social Identity and the Idea of Pilgrimage in the General Prologue." The Chaucer Review, (2003), 37. 4, 285-314; Donald Howard. The Idea of the Canterbury Tales. Berkeley: California UP, 1978). For another view; however, Chaucer attaches importance to the fading of the three estates and the "middle- 
function in the Canterbury Tales might also contribute to this debate along with very few studies on him.

\section{The Delienation of the Roles and Functions of Harry Bailly in the Canterbury Tales}

Performing the authority allocated to him colourfully, Harry Bailly becomes not only the guide but a judge and critic of the Cantrebury Tales. The reader meets Bailly when he serves the pilgrims the best with a peerless meal at the Tabard Inn: "Greet chiere made oure hoost us everichon, /And to the soper sette he us anon. /He served us with vitaille at the beste;/Strong was the wyn, and wel to drynke us leste." (747-750).7 Later, the poet describes the Host as a great man who is plainspoken, wise and welltaught. In the description, the poet also foregrounds the masculinity of the Host as highligted by Scheps and Pugh before. The host is also a cheerful man:

A semely man oure hooste was withalle

For to han been a marchal in an halle.

A large man he was with eyen stepe -

A fairer burgeys is ther noon in chepe -

Boold of his speche, and wys, and wel ytaught,

And of manhod hym lakkede right naught.

Eek therto he was right a myrie man, (751-757)

This description leads some critics, such as Kittredge and Bowden, to praise the Host excessively. According to Bowden, "he is virile, sensible, well-informed and genial" (1948, p.292). Kittredge regards him as "a discreet man, with plenty of tact, one who "knew his way about" (1915, p.162). Later, the Host suggests the well-known tale contest to make the long journey more comfortable and tolerable. Each pilgrim is supposed to tell two tales on the way to Canterbury and two more on the way back. Medieval pilgrims were also known as gifted tale tellers. The pilgrim who tells the best tale with a moral lesson will eat a free meal when they turn back to the inn:

This is the poynt, to speken short and pleyn,

That ech of yow, to shorte with oure weye,

In this viage shal telle tales tweye

To caunterbury-ward, I mene it so,

And homward he shal tellen othere two,

Of aventures that whilom han bifalle.

And which of yow that bereth hym best of alle,

That is to seyn, that telleth in this caas

Tales of best sentence and moost solaas,

Shal have a soper at oure aller cost

Heere in this place, sittynge by this post,

Whan that we come agayn fro caunterbury. (790-801)

grouping", and he depicts the new members of the Middle Ages in The Canterbury Tales (For example, Derek Brewer. "Class Distinction in Chaucer." Speculum 43.2 (1968): 290-305; Helen Phillips. An Introduction to The Canterbury Tales: Reading, Fiction, Context. New York: St. Martin's Press, 2000, and David Aers. Chaucer. Brighton: Harvester, 1986). All Chaucer quotations are taken from The Works of Geoffrey Chaucer (1957). Ed. F. N. Robinson 2nd. Ed. Houghton Mifflin: Boston. 
Here, the host's role as a guide, judge and leader begins. He decides to join the pilgrimage and he declares himself as the guide, judge and the leader of the group. Actually, he says he will join the group if they accept his leadership and rules. So, right at the beginning, he stacks the cards:

Right at myn owene cost, and be youre gyde,

And whoso wole my juggement withseye

Shal paye al that we spenden by the weye.

And if ye vouche sauf that it be so,

Tel me anon, withouten wordes mo,

And I wol erly shape me therfore.

And that he wolde been oure governour,

And oure tales juge and reportour,

And sette a soper at a certeyn pris, (804-815)

Then, the morning comes and the journey begins. Like a rooster, the Host wakes up the pilgrims and reminds of the agreement they made at night. He again declares himself as the judge and they draw cut to determine the first story teller and it is the Knight who draws the shortest cut:

Amorwe, whan that day bigan to sprynge,

Up roos oure hoost, and was oure aller cok,

And there oure hoost bigan his hors areste

And seyde, lordynges, herkneth, if yow leste.

Ye woot youre foreward, and I it yow recorde.

If even-song and morwe-song accorde,

Lat se now who shal telle the firste tale.

As evere mote I drynke wyn or ale,

Whoso be rebel to my juggement

Shal paye for al that by the wey is spent.

Now draweth cut, er that we ferrer twynne;

He which that hath the shorteste shal bigynne. (822-836)

After the Knight told his tale, the pilgrims, especially those of high degree, praise the tale as a noble story and the Host asks the Monk to tell the second tale. Then, the well-known intervention of the Monk comes and he wants to tell the second tale, which is termed by Alfred David as the "Literary Peasants' Rebellion" (1976, p.72). The Host insists that the Monk should tell the second tale after the Knight and as aforementioned this leads some critics to support that the Host observes the three estate order of the Middle Ages:

Whan that the knyght had thus his tale ytoold,

In al the route nas ther yong ne oold

That he ne seyde it was a noble storie, 
Now telleth ye, sir monk, if that ye konne

Somwhat to quite with the knyghtes tale.

The millere, that for dronken was al pale,

So that unnethe upon his hors he sat,

I kan a noble tale for the nones,

With which I wol now quite the knyghtes tale.

Oure hooste saugh that he was dronke of ale,

And seyde, abyd, robyn, my leeve brother;

Som bettre man shal telle us first another.

Abyd, and lat us werken thriftily. (3109- 3131)

The Host, the leader controlling the group, is also likened to a king when he asks the Reeve to stop to talk nonsense and begin to tell his tale: "Whan that oure hoost hadde herd this sermonyng,/ He gan to speke as lordly as a kyng./He seide, what amounteth al this wit?/What shul we speke alday of hooly writ?" (3899-3902). Moreover, as a judge, the Host assesses the tales and even stops the tale tellers. For example, he asks Chaucer the pilgrim to tell a cheerful story, yet later he stops him as he does not like his story with rhyme in verse and asks him to tell a story in prose but make it cheerful or didactic:

Telle us a tale of myrthe, and that anon.

Hooste, quod I, ne beth nat yvele apayd,

For oother tale certes kan I noon,

But of a rym I lerned longe agoon.

Ye, that is good, quod he; now shul we heere

Som deyntee thyng, me thynketh by his cheere. (706- 711)

Namoore of this, for goddes dignitee,

Quod oure hooste, for thou makest me

Sire, at o word, thou shalt no lenger ryme.

Lat se wher thou kanst tellen aught in geeste,

Or telle in prose somwhat, at the leeste,

In which ther be som murthe or som doctryne (919-935)

As another example, when the Monk lists his stories of tragedy, like the Knight, the Host interrupts him and asks a more interesting story in hunting:

Sire monk, namoore of this, so God yow blesse!

I sholde er this han fallen doun for sleep,

Althogh the slough had never been so deep;

Thanne hadde your tale al be toold in veyn.

For certeinly, as that thise clerkes seyn, 
Whereas a man may have noon audience, Noght helpeth it to tellen his sentence.

Sir, sey somwhat of huntyng, I yow preye. (2788- 2805)

As introduced in his first appearance, Bailly is an outspoken, a jovial and sagacious character. His masculinity, which is in line with his governing position, is also foregrounded in his description. Selfreliant and assertive, Bailly participates in the pilgrimage on the condition that he becomes the leader of the group. Putting forward a tale-telling contest, our Host composes the framework of the text and in a way grows into the co-author of the text. Evaluating the tales and commenting on them, he also undertakes the mission of a critic. Yet, his masculine and leading demeanour is disrupted by a minor character, his wife, Goodelief, which takes the reader to another hot debate in Chaucer criticism.

\section{A "So-Called" Absent character from the stage: Goodelief, The Wife of Harry Bailly}

Another noteworthy point with regard to the role and function of the Host might be observed in his attitudes towards women, which might redound to the debate in Chaucer criticism. ${ }^{8}$ Talking to males, the Host generally talks cynically and sarcastically, for example to the Monk, the Reeve and the Cook. Yet, when one looks at his words to the Prioress, a gentleman appears with kind words. Trying not to offend the Prioress, the Host kindly asks the Prioress to tell the next tale:

Another tale; and with that word he sayde,

As curteisly as it had been a mayde,

My lady prioresse, by youre leve,

So that I wiste I sholde yow nat greve,

I wolde demen that ye tellen sholde

A tale next, if so were that ye wolde.

Now wol ye vouche sauf, my lady deere? (445-451)

In another example, when the speech of the Wife of Bath is interrupted by the pilgrims, the Host asks them to stop and let her tell her story (850-853). The Host also gets very angry when he learns that the Miller's story will be about a cuckolded husband and an immoral wife. He says do not smear the women and at that time we learn that he is also married and has a wife (3134-3135). The Host's having a wife leads the reader to the other side of the coin. The Host has various roles which are all dominating ones. However, he is a husband as well. In the Monk's Prologue, the reader learns about the Host's wife and is totally bewildered by the way how his wife treats this governing figure. Bailly talks about his wife three times: After the Clerk of Oxford's Tale, shortly in the epilogue to the Merchant's Tale and in the Monk's

8 To a group of critics, Chaucer might be regarded as a proto-feminist due to his treatment of women in his Canterbury Tales such as the Wife of Bath and the Prioress to whom he has given voice in a time when women were expected to be passive. The women are also put on a pedestal in some tales told by male characters such as The Knight's Tale and the Franklin's Tale (See for example, "New Feminist Approaches to Chaucer: Introduction" by Samantha Katz Seal and Nicole Sidhu, The Chaucer Review, (2019), 54.3: 224-229; and "He conquered al the regne of Femenye': feminist criticism of Chaucer" by Marion Wynne-Davies, Feminist Criticism, (1992), 4.2: 107-113). Quite the contrary, another group of critics reckon Chaucer as a misogynist on account of some of his works such as Troilus and Criseyde and The Miller's Tale and The Merchant's Tale in The Canterbury Tales (For example, "Chaucer and the Misogynist Tradition in The Canterbury Tales” by Edward Raupp, 12th International Scientific Conference, Gori State Teaching University (2019); “January's Misogynist Merchant: The Theme of Sight in Chaucer's Merchant and “The Merchant's Tale" by Stephanie A Tolliver, The University of Virginia's College at Wise, 2001). 
Prologue after the Tale of Melibee. Upon listening to the tale of the Clerk of Oxford on patient Griselda, the Host wishes that his wife could hear this story:

This worthy clerk, whan ended was his tale,

Oure hooste seyde, and swoor, by goddes bondes,

Me were levere than a barel ale

My wyf at hoom had herd this legende ones!

This is a gentil tale for the nones, (1213-1217)

In a similar vein, after listening to the tale of Melibee, Bailly, delighted with the story, states that he wants his wife to hear the tale to take a lesson from Dame Prudence in endurance. Unlike Prudence, his wife, Goodelief, 9 is for violence and fight. She wants the Host to fight with her neigbours to protect her, and if he does dot, she calls him coward ape and grouchy, and threatens him to show the door. The Host is worried about turning into a murderer one day, a murderer of his neighbours, but he can find no way out and he is helpless in the face of his wife's dominant nature:

Whan ended was my tale of melibee,

And of prudence and hire benignytee,

Oure hooste seyde, as I am feithful man,

That goodelief, my wyf, hadde herd this tale!

For she nys no thyng of swich pacience

As was this melibeus wyf prudence.

By goddes bones! whan I bete my knaves,

She bryngeth me forth the grete clobbed staves,

And crieth, -- slee the dogges everichoon,

And brek hem, bothe bak and every boon! --

And if that any neighebor of myne

Wol nat in chirche to my wyf enclyne,

Or be so hardy to hire to trespace,

Whan she comth hoom she rampeth in my face,

And crieth, -- false coward, wrek thy wyf!

By corpus bones, I wol have thy knyf,

And thou shalt have my distaf and go spynne! --

Fro day to nyght right thus she wol bigynne.

-allas! -- she seith, -- that evere I was shape

To wedden a milksop, or a coward ape,

That wol been overlad with every wight!

Thou darst nat stonden by thy wyves right! --

This is my lif, but if that I wol fighte;

As foregrounded by Malone, Godelieve was the name of a Flemish saint. Her submission and meekness were highlighted in the hagiographers of the twelfth and thirteenth centuries. In Chaucer's time, the name was widely used in Kent. Harry Bailly's wife's name Goodelief is sarcastic as she has a reverse character (209). 
And out at dore anon I moot me dighte,

Or elles I am but lost, but if that I

Be lik a wilde leoun, fool-hardy.

I woot wel she wol do me slee som day

Som neighebor, and thanne go my way;

For I am perilous with knyf in honde,

$\mathrm{Al}$ be it that I dar nat hire withstonde,

For she is byg in armes, by my feith:

That shal he fynde that hire mysdooth or seith, --

But lat us passe awey fro this mateere. (1889-1923)

Appertaining to the Host's relationship to his wife, Page points out that "Harry Bailly suffers from one perpetual, gnawing humiliation: he is a henpecked husband" (1969, p.4). Similarly, to Bowden, "[t]his agreeably fashioned man, large of body and extremely virile is nevertheless dominated and abused at home" (1948, p.292). Therefore, the governing position of the Host is turned upside down by his wife. Pug's argument encapsulates what Chaucer achieves through this minor character: The wife of the Host "inverts their gendered roles in the domestic space" (2006, p.54). In fact, the wife reverses the traditional gender spheres by calling her husband coward and puts her husband in feminine sphere by saying if she had a knife, she would attack the neighbours and her husband would spin with her distaff. That is how the Host's domineering role in the text is hampered by his wife.

More importantly, reading between the lines and examining this minor character, the reader meets another Wife of Bath. Analogous to Alison, the Wife of Bath, flirting with men and bragging of her five husbands, Goodelief does not submit to male dominance. A revolutionary character for her age, the Wife of Bath teaches a lesson to men through her story on a knight. In fact, in the Middle Ages, misogyny was prevalent; the secondary status of women and their obedience to men were traditionally acknowledged. Apart from the chaste and obedient role assigned to them deriving from Virgin Mary, women were regarded as inferior and rebellious depending on the image of Eve. Therefore, these revolutionary female characters of Chaucer are also source of debate in Chaucer criticism. For example, to some critics, through the Wife of Bath, Chaucer aims to guard women against the misogyny extensive in the Middle Ages. However, to another group of critics, the Wife of Bath embodies the medieval female stereotypes. ${ }^{10}$ This split in opinion might be viable for all of the radical female characters of Chaucer, including Goodelief. Married at the age of twelve, leaving five husbands behind, the Wife of Bath is the well known example of those radical characters. She even defies the authorities of the Church and alleges the upper hand in marriage:

Experience, though noon auctoritee/

Were in this world, is right ynogh for me/

[...] Of tribulacion in marriage,/

Of which I am expert in al myn age. (1-4).

Thus, the Wife of Bath possesses male traits by claiming her independence and authority. She even associates herself with the biblical characters such as Solomon and Abraham. ${ }^{11}$ Similar to the Wife of

S. H. Rigby, English Society in the Later Middle Ages: Class, Status and Gender (London: Macmillan, 1995), 133-134. "Why sholde men thane speke of it vileynye?/Lo, here the wise kyng, daun salomon; /I trowe he hadde wyves mo than oon./ As wolde God it were leveful unto me/ To be refreshed half so ofte as he!" (34-38). 
Bath, Goodelief asks for the authority in marriage and even suggests her husband to change gender roles. Absent from the stage, let alone a story of her own, Goodelief succeedes in arousing a great interest in reader. Both wives, through their experience and defying nature, resist the male authority and step out the feminine sphere. Regardless of the fact that they are recognised as Evelike figures in the medieval mind, Deliahs of Solomons or Bathshebas of Davids for Sir Gawain, they are the pioneers of feminism, claiming women's rights on the ground of the equality of males and females. It is also compelling that they were created by the pen of a male belonging to a society known for its misogyny.

In spite of being a troublemaker to her husband and to men in general, Goodelief might be considered as a figure whom Bailly as a character owes much. Bailly is one of the characters who does not tell a story in the tale-telling contest. To Williams, although Bailly does not tell a tale, he tells a tale about marriage via his absent wife. This story is also vital for evaluating Bailly as a character and Chaucer's representation of marriage and wifehood (2008, p.383). Indeed, marriage is one of the popular themes for the Canterbury pilgrims. The Wife of Bath tells a story of the inevitability of female superiorty in marriage. The Clerk of Oxford replies to the tale of the Wife of Bath and tells the story of patient Griselda. The Merchant joins the discussion and tells the story of an old man Januarie and his young unfaithful wife May. Finally, the Franklin tells the story of a knight, Arviragus and his wife Dorigan and highlights marriage as a respectable union. In his reputed article, "Chaucer's Discussion of Marriage," Kittredge explores the stories of these mentioned characters under the title of "the marriage group" succeeded by abundant critics. ${ }^{12}$ Now, it seems that a major character is missing in this renowned group.

Consequently, respecting his relationships with women, Bailly, a valiant and manly man, behaves so gentle and shields them against the possible attacks by pilgrims, which contributes much to his character. This protection might remind the reader of the Queen Philippa, the wife of Edward III, who is said to ask Chaucer to write a work to praise women (The Legend of Good Women) after his work Troilus and Criseyde in which women are depicted as traitors. To imitate Chaucer's words, this ilke worthy and domineering Host is mistreated by his wife and is transformed into a docile character at home. Inverting the gender roles, Goodelief acts the Wife of Bath and strongly opposes male rule. While listening to the stories of the pilgrims, Bailly, in parts, tells the story of his wife and reflects upon marriage and gender relationships of his time, adding another function to his character.

\section{Conclusion}

Despite being an ignored character compared to the other pilgrims, the Host of Chaucer's The Canterbury Tales emerges as one of the more indelible creations in literature. A portrayal of an actual inn-keeper of the fourteenth-century, courteous especially to women, masculine, solemn and imperious, Bailly is a character of the same depth of the Knight or the Prioress. A guide, a judge and a critic, Bailly is the character contributing the most to the realism of the text. As a newly rising middle-class member, Bailly is the embodiment of both the changing and constant values of the medieval society. Moreover, through Bailly, the reader meets another Wife of Bath, Goodelief, who is a man-eater dominating men.

\footnotetext{
See among others, George Lyman Kittredge, “Chaucer's Discussion of Marriage”, Modern. Philology 9 (1912): 435-67; John S. Kenyon, "Further Notes on the Marriage Group in the "Canterbury Tales", The Journal of English and Germanic Philology 15.2 (1916): 282-288; Donald, R. Howard. "The Conclusion of the Marriage Group Chaucer and the Human Condition", Modern Philology 57.4, (1960): 223- 232; James L. Hodge, "The marriage group: Precarious equilibrium", English Studies, 46, (1965): 289-300; Joseph J. Mogan, Jr. "Chaucer and the Bona Matrimonii", The Chaucer Review 4.2 (1969):123-141; Clair C. Olson "The Interludes of the Marriage Group in the Canterbury Tales" in Chaucer and Middle English Studies, Edited By Beryl Rowland, 1974, London, Routledge, 1-9; Warren Ginsberg, "The Lineaments of Desire: Wish-Fulfillment in Chaucer's Marriage Group", Criticism 25.3 (1983): 197-210, and Elizabeth Scala, "The Women in Chaucer's “Marriage Group"” MFF 45 . 1 (2009): 50-56.
} 
The wife of the Host in a way converts the hue of the Host by reversing the gender roles. Goodelief, a radical female character bequeathed by Chaucer to Charlotte Bronte and Virginia Woolf, takes her place in the realm of women. What is more, who says the Host does not tell a story! Analogous to the Wife of Bath, the Clerk of Oxford, the Merchant and the Franklin, the Host tells a story of marriage and gender relationships; thus, deserves to ask for a seat in the well-known marriage group. Goodelief might not have heard the stories of Griselda and Prudence; yet, we have received the story of Bailly very well. As the last word, Bailly is a nonpareil character without whom the Canterbury Tales is incomplete and by whom Chaucer exhibits his mastery once again.

\section{References}

Bowden, M. (1948). A commentary on the general prologue to the Canterbury Tales. Macmillan. Chaucer, G. (1957). The Canterbury Tales. Robinson, F. N. (Ed.). 2nd. ed. Houghton Mifflin.

David, A. (1976). The strumpet muse: Art and morals in Chaucer's poetry. Indiana University Press.

Fredrica, W. A. (1978). Harry Bailly's contribution to the realism of Chaucer's Canterbury Tales. [Master Thesis, Florida Atlantic University].

Keen, W. (1969). "To Doon Yow Ese": A study of the host in the general prologue of the Canterbury Tales? Topic, 17, 5-18.

Kittredge, G. L. (1915). Chaucer and his poetry. Mass.

Legouis, E. (1961). Geoffrey Chaucer. (L. L. Voix, Trans.). Russell \& Russell.

Lumiansky, R. M. (1955). Of sondry folk. University of Texas Press at Austin.

Malone, K. (1950). Harry Bailey and Godelief. English Studies, 31, 2 o 9 -1 5.

Manly, J. M. (1926). Some new light on Chaucer. H. Holt.

Mann, J. (1973). Chaucer and Medieval estates satire. Cambridge University Press.

Muscatine, C. (1957). Chaucer and the French tradition. University of California Press.

Page, B. (1969). Concerning the host. The Chaucer Review, 4 (1), 1-13.

Pichaske, D. R., \& Sweetland, L. (1977). Chaucer on the Medieval monarchy: Harry Bailly in the Canterbury Tales. The Chaucer Review, 11 (3), 179-200.

Pugh, T. (2006). Queering Harry Bailly: Gendered carnival, social ideologies, and masculinity under duress in the Canterbury Tales. The Chaucer Review, 41 (1), 39-69.

Richardson, C. C. (1970). The function of the host in the Canterbury Tales. Texas Studies in Literature and Language, 12 (3), 325-344.

Scheps, W. (1975). Up roos oure hoost, and was oure aller cok: Harry Bailly's tale-telling competition. The Chaucer Review, 10 (2), 113-128.

Sedgwick, H. D. (1934). Dan Chaucer. AMS Press.

Williams, T. (2008). The host, his wife, and their communities in the Canterbury Tales. The Chaucer Review, 42 (4), 383-408. 